Four new epiphytic species in the Micarea prasina group from Europe

\author{
Launis, Annina
}

2019-01

Launis , A , Pykälä , J , van den Boom , P , Serusiaux , E \& Myllys , L 2019 , ' Four new

epiphytic species in the Micarea prasina group from Europe ' , Lichenologist , vol. 51 , no. 1 , pp. 7-25 . https://doi.org/10.1017/S0024282918000555

http://hdl.handle.net/10138/326194

https://doi.org/10.1017/S0024282918000555

CC BY-NC-ND

acceptedVersion

Downloaded from Helda, University of Helsinki institutional repository.

This is an electronic reprint of the original article.

This reprint may differ from the original in pagination and typographic detail.

Please cite the original version. 


\title{
Four new epiphytic species in the Micarea prasina group from Europe
}

\author{
Annina Launis, Juha Pykälä, Pieter van den Boom, Emmanuël Sérusiaux \& Leena \\ Myllys
}

A. Launis (corresponding author) and L. Myllys: Botany unit, Finnish Museum of Natural History, P.O. Box 7, FI-00014 University of Helsinki, Finland. Email: annina.launis@ helsinki.fi (2020 onwards: annina.kantelinen@helsinki.fi).

J. Pykälä: Natural Environment Centre, Finnish Environment Institute, P.O. Box 140, FI-00251 Helsinki, Finland.

P. van den Boom: Arafura 16, NL-5691 JA Son, the Netherlands.

E. Sérusiaux: Evolution and Conservation Biology Unit, InBios research center, University of Liège, Sart Tilman B22, B-4000 Liège, Belgium.

\begin{abstract}
In this study we clarify the phylogeny and reassess the current taxonomy of the Micarea prasina group focusing especially on $M$. byssacea and $M$. micrococca complexes. The phylogeny was investigated using ITS, $\mathrm{mtSSU}$ and $\mathrm{Mcm} 7$ regions from 25 taxa belonging to the $M$. prasina group. A total of 107 new sequences were generated. The data was analyzed using maximum parsimony and maximum likelihood methods. The results reveal five undescribed well-supported lineages. Four of the lineages represent new species described as Micarea pseudomicrococca Launis \& Myllys sp. nov., Micarea czarnotae Launis, van den Boom, Sérusiaux \& Myllys sp. nov., Micarea microareolata Launis, Pykälä \& Myllys sp. nov. and Micarea laeta Launis \& Myllys sp. nov. In addition, a fifth lineage was discovered that requires further studies. $M$. pseudomicrococca is characterized by olive green granular thallus, small creme white or brownish apothecia lacking the Sedifoliagrey pigment and two types of paraphyses up to $2 \mu \mathrm{m}$ wide. $M$. czarnotae forms granular, densely granular or continuous olive green thallus, convex to hemispherical apothecia often with the Sedifolia-grey pigment and no crystalline granules in the thallus. M. microareolata is characterized by \pm pale green areolate thallus (composed of goniocysts), cream white apothecia lacking the Sedifolia-grey pigment and narrow spores. $M$. laeta has vivid to olive green granular thallus, pale apothecia lacking the Sedifolia-grey pigment and wider spores compared to M. microareolata. Descriptions, illustrations and an identification key are provided for the new species. Crystalline granules are introduced as a novel species-level character for Micarea.
\end{abstract}

KEY WORDS: crystalline granules, ITS, lichens, Mcm7, mtSSU, taxonomy. 


\section{INTRODUCTION}

The taxonomy of Micarea Fr., a crustose lichen genus in the family Pilocarpaceae, is insufficiently known largely owing to a small amount of morphological characters and difficulties in their interpretation. The genus comprises c. 100 species and occurs on all continents (Kirk et al. 2008; Coppins 2009). It is best known and most widely collected from Europe where it is widespread and common. But even after two monographic treatments of the European species of the genus (Coppins 1983; Czarnota 2007), new species and distribution data are frequently published from Europe and Macaronesia (Czarnota \& Guzow-Krzemińska 2010; Svensson \& Thor 2011; van den Boom \& Ertz 2014; Guzow-Krzemińska et al. 2016; van den Boom et al. 2017) as well as from other less known areas (Cácares et al. 2013; Aptroot \& Cácares 2014; Barton \& Lendemer 2014; Brand et al. 2014; Córdova-Chávez et al. 2014; Launis \& Myllys 2014; McCarthy \& Elix 2016). In many cases, DNA based phylogenies have been necessary for unveiling the species diversity.

Recent molecular phylogenies have shown that Micarea is paraphyletic (Andersen \& Ekman 2005; Sérusiaux et al. 2010), even after the introduction of a new genus Brianaria S. Ekman \& Svensson for the M. sylvicola group (Ekman \& Svensson 2014). Species delimitation has perhaps been especially problematic in the $M$. prasina group, which includes the type species of the genus, M. prasina Fr. (Andersen \& Ekman 2005; Sérusiaux et al. 2010; Schmull et al. 2011). In his European monograph, Coppins (1983) delimited the group based on morphological, anatomical and chemical features: all species have "micareoid" photobiont (a coccoid green alga with cells 4-7.5 $\mu \mathrm{m}$ in diameter), immarginate apothecia, branched paraphyses and an ascus of the Micarea-type (Hafellner 1984). The majority of the species produce the Sedifolia-grey pigment (K+ violet, C+ violet), which is typically present in the apothecia and pycnidia (Coppins 1983; Czarnota \& GuzowKrzemińska 2010). According to Coppins (1983), the group comprised M. prasina, M. hedlundii Coppins, $M$. levicula (Nyl.) Coppins and with some uncertainty also M. misella (Nyl.) Hedl., M. melanobola (Nyl.) and M. synotheoides (Nyl.) Coppins. Micarea prasina was treated in a wide sense having variable morphology and including three chemical races. The species was eventually shown non-monophyletic and two distinct lineages were described as new species: M. subviridescens (Nyl.) Hedl. and M. micrococca (Körb.) Gams ex Coppins (Coppins 2002). Furthermore, M. xanthonica Coppins \& Tønsberg (2001) and M. viridileprosa Coppins \& van den Boom (2001) were recognized as members of the M. prasina group. 
Recently, Czarnota \& Guzow-Krzemińska (2010) conducted a phylogenetic study, based on mtSSU sequences, to investigate species delimitation in the $M$. prasina group. They concluded that $M$. micrococca includes three distinct lineages, and recognized two of them at species level, M. byssacea (Th. Fr.) Czarnota, Guz.-Krzemiń., Coppins and M. micrococca (Körb.) Gams ex Coppins s. str. A third lineage did not have clear morphological, distributional or ecological characters to be recognized as a separate species. Their results showed that the variation within the $M$. prasina group, and more specifically in $M$. micrococca and $M$. byssacea, needs to be studied in more detail using information from several gene regions.

According to previous single-gene phylogenetic studies (Czarnota \& Guzow-Krzemińska 2010; GuzowKrzemińska et al. 2016), M. byssacea and $M$. micrococca form a monophyletic species group together with $M$. viridileprosa and the undescribed lineage discovered by Czarnota \& Guzow-Krzemińska (2010). In general, M. byssacea and M. micrococca are characterized by immarginate, convex to hemispherical apothecia and thallus composed of goniocysts. The species are mostly epiphytes or rarely grow on decaying wood in various woodland habitats. More specifically, the species in the M. byssacea and M. micrococca complexes differ from each other in the size of apothecia: species in the M. byssacea complex form larger apothecia $(0.3-0.6$ in diameter) than the species in the M. micrococca complex (0.2-0.4 in diameter).

Here we further investigate the species diversity within $M$. byssacea and $M$. micrococca species complexes. We use phenotypic characters and multiloci sequence data (ITS, mtSSU and Mcm7) to examine the phylogenetic relationships and species delimitation in the two species complexes. Due to small amount of distinct phenotypic traits, the first author decided to search for new characters for species delimitation. Crystalline granules in sections of apothecia and thallus, investigated in polarized light, have been used in the identification of crustose lichen species in genera such as Lecanora and Mycobilimbia (Brodo 1984; Spribille et al. 2011). In these genera, the presence, distribution, size and solubility of the granules are considered important features. However, their significance in many lichen groups, including Micarea, is still poorly known (Orange et al. 2010). 


\section{MATERIAL AND METHODS}

25 taxa corresponding to the M. prasina group (sensu Andersen 2004; Czarnota \& Guzow-Krzemińska 2010; Sérusiaux et al. 2010) were used in the study. The study is based on material collected from Finland, the Netherlands, Poland, Sweden, Scotland and USA during 2002-2015. Type material of related Micarea species from the herbaria G, H, and UPS was studied for comparison, and the type specimens placed under synonymy of Micarea micrococca by Czarnota (2007) were investigated. Detailed information of the material used in the phylogenetic analyses is presented in Table 1 .

\section{DNA extraction and sequencing}

DNA was extracted from apothecia (1-3) of max. 3 years old specimens. For most specimens DNA was extracted using DNeasy® Blood \& Tissue kit by Qiagen following the protocol described in Myllys et al. (2011). PCR reactions were prepared using PuReTaq Ready-To-Go PCR beads (GE Healthcare). The $25 \mu \mathrm{L}$ reaction volume contained $19 \mu \mathrm{L} \mathrm{dH} 2 \mathrm{O}, 1 \mu \mathrm{L}$ of each primer $(10 \mu \mathrm{M})$ and $4 \mu \mathrm{L}$ extracted DNA.

For ITS-region PCR was run under following conditions: initial denaturation for $5 \mathrm{~min}$ at $95{ }^{\circ} \mathrm{C}$ followed by five cycles of $30 \mathrm{~s}$ at $95{ }^{\circ} \mathrm{C}$ (denaturation), $30 \mathrm{~s}$ at $58{ }^{\circ} \mathrm{C}$ (annealing), and $1 \mathrm{~min}$ at $72{ }^{\circ} \mathrm{C}$ (extension); in the remaining 40 cycles the annealing temperature was decreased to $56{ }^{\circ} \mathrm{C}$; the PCR schedule ended with a final extension for $7 \mathrm{~min}$ at $72{ }^{\circ} \mathrm{C}$. Primers ITS1-LM (Myllys et al. 1999) and ITS4 (White et al. 1990) were used both for PCR amplification and sequencing of the nuclear ribosomal ITS region.

For mtSSU-region PCR was run under following conditions: initial denaturation for $10 \mathrm{~min}$ at $95^{\circ} \mathrm{C}$ followed by six cycles of $1 \mathrm{~min}$ at $95{ }^{\circ} \mathrm{C}$ (denaturation), $1 \mathrm{~min}$ at $62{ }^{\circ} \mathrm{C}$ (annealing), and $105 \mathrm{~s}$ at $72{ }^{\circ} \mathrm{C}$ (extension); in the remaining 35 cycles the annealing temperature was decreased to $56^{\circ} \mathrm{C}$ and extension time at $1 \mathrm{~min}$; the PCR schedule ended with a final extension for $10 \mathrm{~min}$ at $72{ }^{\circ} \mathrm{C}$. Primers $\mathrm{mrSSU} 1$ and $\mathrm{mrSSU} 3 \mathrm{R}$ (Zoller et al. 1999) were used both for PCR amplification and sequencing.

For $M c m 7$ region PCR was run under two different conditions depending on the primers selected: initial denaturation for $10 \mathrm{~min}$ at $94{ }^{\circ} \mathrm{C}$ followed by 38 cycles of $45 \mathrm{~s}$ at $94{ }^{\circ} \mathrm{C}$ (denaturation), $50 \mathrm{~s}$ at $55 / 56{ }^{\circ} \mathrm{C}$ 
(annealing), and $1 \mathrm{~min}$ at $72{ }^{\circ} \mathrm{C}$ (extension); the PCR schedule ended with a final extension for 5 min at $72{ }^{\circ} \mathrm{C}$. Primers x.Mcm7.f (Leavitt et al. 2011) and Mcm7.1348R (Schmitt et al. 2009) or newly generated primers $M c m 7 \_A L 1 r \quad\left(5^{\prime} \quad\right.$ CKGTCACARCSAAGCARTAYACACCTATG $\left.3^{\prime}\right)$ and Mcm7_AL2f $\quad\left(5^{\prime}\right.$ CTTTYGTCACWCCSCCRATKAGRAGC 3') were used both for PCR amplification and sequencing. The annealing temperature for the first primer pair was $56^{\circ} \mathrm{C}$ and for the second newly generated primer pair $55^{\circ} \mathrm{C}$. PCR products were cleaned and sequenced by Macrogen Inc., South Korea (www.macrogen.com).

\section{Phylogenetic analyses}

107 sequences were generated for the analysis and 19 were obtained from GenBank. Micarea peliocarpa was used as outgroup for the studied M. prasina group.

A total of 29 ITS sequences, $59 \mathrm{mtSSU}$ sequences and $38 \mathrm{Mcm} 7$ sequences, were aligned separately with MUSCLE v.3.8.31 (Edgar 2004) using EMBL-EBI's freely available web service (http://www.ebi.ac.uk/Tools/msa/muscle/). The single gene trees did not show any strongly supported conflicts according to Kauff \& Lutzoni (2002) method ( $\geq 75 \%$ bootstrap values) and the three matrices were combined into a concatenated matrix in MacClade 4.08 (Maddison \& Maddison 2005). Portions of the alignment with ambiguous positions that might not have been homologous were excluded. The concatenated data set including 63 terminals was subjected to maximum parsimony analysis as implemented in TNT v.1.1 (Goloboff et al. 2008) and to maximum likelihood analysis using RAxML v.8.1.15 (Stamatakis 2014) located at CSC-IT Center for Science (http://www.csc.fi/english) internet server. The parsimony analysis was performed using traditional search with random addition of sequences with 100 replicates and TBR branch swapping algorithm. Ten trees were saved for each replicate and gaps were treated as missing data. Node support was estimated using the bootstrapping method with 1000 replicates. Bootstrap values $>75 \%$ are considered significant. For the maximum likelihood analysis the combined data set was assigned to seven partitions: ITS1, 5.8S, ITS2, $\mathrm{mtSSU}$ and each of three codon positions of $\mathrm{Mcm}$. The hypervariable region in the end of the mtSSU was removed from the analyses (characters 649 - 804 in the alignment). We used an independent GTR+G model for each subset and branch lengths were assumed proportional across subsets. The tree with the highest likelihood from 36 individual runs was selected. Node support was estimated with 1000 bootstrap replicates using the rapid bootstrap algorithm. 


\section{Morphology and chemistry}

Hand cut apothecial sections and squashed thallus preparations were examined with a dissecting or compound microscope. Ascospore dimensions and other anatomical measurements were made in water. Chemical spot tests were performed under a compound microscope using sodium hypochlorite (C) and $10 \%$ potassium hydroxide (K) (Orange et al. 2010). Pigments were characterized following Coppins (1983), Meyer and Printzen (2000) and Czarnota (2007). Specimens were further studied using thin-layer chromatography (solvent C) following Culberson and Kristinsson (1970) and Orange et al. (2010) and investigating crystalline granules by using compound microscope with polarization lenses. The crystalline granules were studied from sequenced specimens within the M. micrococca and $M$. byssacea complexes, and from M. prasina s.lato. Specimens are deposited in BG, E, GPN, H and LG.

\section{RESULTS}

In this study a total of 107 new sequences were generated and 19 sequences were downloaded from GenBank. The final 3-loci data set consisted of 126 sequences and of 1825 characters of which 720 were parsimonyinformative. Since the topologies of the maximum likelihood and TNT analyses did not show any strongly supported conflicts, only the tree obtained from the maximum likelihood analysis is shown (Fig. 1).

Our multiloci phylogeny agrees with the previous single locus phylogenies of the group (Czarnota \& GuzowKrzemińska 2010; Guzow-Krzemińska et al. 2016) and shows that Micarea prasina group is strongly supported and monophyletic. Furthermore, M. byssacea and M. micrococca are sister groups and form strongly supported monophyletic species complexes with five previously undescribed new lineages.

The Micarea byssacea complex is divided into four lineages: 1) Micarea microareolata, represented by nine specimens in our study (Fig 2), 2) a single unidentified individual (lineage A in Fig 1 and 3) collected from Scotland, 3) Micarea byssacea s. str., with three specimens (Fig 3), and 4) Micarea laeta, represented by twelve specimens (Fig 2). Micarea byssacea s. str. and M. laeta form a strongly supported sister group. Also, a cryptic lineage is quite likely present within $M$. microareolata. 
The Micarea micrococca complex consists of four distinct well supported groups. Micarea viridileprosa is strongly supported as sister to M. micrococca s. str. (Czarnota \& Guzow-Krzemińska 2010). The first two, i.e. M. micrococca and $M$. viridileprosa form a strongly supported sister group. The remaining two clades represent new species: Micarea czarnotae with seven specimens (corresponding to M. micrococca "B" in Czarnota \& Guzow-Krzemińska 2010) and M. pseudomicrococca, represented by four specimens in our phylogeny (Fig 1).

Small crystalline granules, soluble in K, were detected in all studied species in polarized light. Such granules were present in both hymenium and thallus in M. byssacea, M. laeta, M. microareolata, M. pseudomicrococca and M. micrococca. Contrary to other species, M. czarnotae formed granules only in the hymenium and never in the thallus. Crystalline granules were also studied in M. prasina s. str. (Fig. 4) because of its morphological resemblance to the species in the M. byssacea and M. micrococca complexes. Micarea prasina formed crystals in the epihymenium and the thallus, but unlike the other species, almost never in the hymenium (M. prasina sample AY756452, resolved as a different branch in the analyses was not studied). Without exception, crystalline features were represented identically in all individuals within each studied species. We note however, that the crystalline granules were studied only from sequenced specimens, as this is the most reliable way for species identification. Therefore the number of studies specimens was limited. Crystalline features are presented in more detail in Fig 4.

\section{DISCUSSION}

Our multiloci phylogeny relates well with the previous single-locus phylogenies of the Micarea prasina group (Czarnota \& Guzow-Krzemińska 2010; Guzow-Krzemińska et al. 2016; van den Boom et al. 2017). Generally the clades were strongly supported despite the rather high amount of missing data especially in the ITS regions (see Table 1). Based on mainly new collections, our study revealed five previously undescribed well-supported lineages. These lineages are also supported by morphological traits. Four of the lineages represent new species, for which we propose the following names: Micarea pseudomicrococca Launis \& Myllys, Micarea czarnotae 
Launis, van den Boom, Sérusiaux \& Myllys, Micarea microareolata Launis, Pykälä \& Myllys and M. laeta Launis \& Myllys.

The fifth previously undescribed lineage is represented only by a single sample collected from decaying wood in Eastern Scotland. This putative new taxon forms pallid $0.2-0.7 \mathrm{~mm}$ wide apothecia resembling in size and shape those of M. byssacea, except that they always lack the Sedifolia-grey pigment ( $\mathrm{K}-$ and $\mathrm{C}-$ ). Furthermore, the taxon forms bright green thallus composed of goniocysts highly resembling the thallus of M. micrococca. Due to the insufficient amount of material no taxonomic innovation is proposed at the moment. This result indicates that the diversity within the $M$. prasina group, and more precisely within the $M$. byssacea complex, is still insufficiently known, even in the well-studied areas of Europe.

Two of the new species, Micarea czarnotae and M. pseudomicrococca belong to $M$. micrococca complex while M. microareolata is part of the M. byssacea complex. Our results show that species in the two groups differ mainly in the size and shape of the apothecia. Species in the M. micrococca complex, including the new species described in this study, have small apothecia that are plane, convex, hemispherical or sometimes tuberculate and $0.2-0.4 \mathrm{~mm}$ wide. Species in the $M$. byssacea complex are characterized by wider apothecia that are $0.3-0.6(-0.7) \mathrm{mm}$ in diam., adnate, convex to hemispherical or sometimes tuberculate. As presented below, our results based on molecular data show that these subtle phenotypic differences are significant in defining species boundaries in the M. byssacea and M. micrococca complexes.

Micarea czarnotae produces the Sedifolia-grey pigment (K+ violet and $\mathrm{C}+$ violet), whereas $M$. micrococca and M. pseudomicrococca do not. Furthermore, thallus morphology and color differ between the species: $M$. micrococca has a bright green or olive green thallus composed of coalescing granules, whereas $M$. pseudomicrococca has an olive green minutely granular thallus, and M. czarnotae an olive green, densely granular, warted-areolate or, when well-developed, an almost continuous and cracked thallus.

Micarea byssacea produces the Sedifolia-grey pigment ( $\mathrm{K}+$ violet and $\mathrm{C}+\mathrm{violet})$, whereas M. laeta and $M$. microareolata do not. Furthermore, thallus color and morphology differ between the species in the M. byssacea complex: $M$. byssacea is usually characterized by an olive green minutely granular thallus, $M$. microareolata 
by a whitish or pale olive green thallus composed of small areolae, and M. laeta by a vivid green or olivaceous thallus, composed of coalescing granules.

Finding appropriate morphological and chemical characters is one of the major challenges in species delimitation of lichen-forming fungi, especially in groups where characters are few or highly homoplastic (see Lumbsch \& Leavitt 2011; Mark et al. 2016). Crystalline granules have not been previously investigated in the genus Micarea and thus their value in the identification of Micarea spp. has been unknown. Our study shows that crystalline features are, at least in some cases, useful as a species-level character. The presence and distribution of such granules were found unique in $M$. prasina (granules only in the epihymenium) and in $M$. czarnotae (no crystalline granules in the thallus). Within the $M$. byssacea complex, crystalline features were not found useful, as the size and distribution of these granules were shown to be identical amongst the species. Many of the crystalline deposits found in lichens are composed of calcium oxalate (Orange et al. 2010), but detailed composition of the crystalline granules detected in the $M$. prasina group is unknown. The presence, distribution and amount of crystals were shown to be unaffected by light conditions, apothecial pigments or other anatomical or environmental features. The crystalline granules were studied from sequenced specimens, as this was the most reliable way to delimit species in this phenotypically challenging group. But consequently, this sets a limit to the number of specimens that we were able to search the crystals from. Therefore, a larger data set is needed to better understand the reliability of the new feature as a species-level character within Micarea.

Several taxonomic problems in the $M$. prasina group still remain to be addressed. In light of this study, and those of Czarnota (2007), Czarnota \& Guzow-Krzemińska (2010), Brand et al. (2014), Guzow-Kremínska et al. (2016) and van den Boom et al. (2017), some of the type specimens synonymized with M. prasina Fr., e.g. M. melanobola (Nyl.) Coppins, should be investigated in more detail. Also, the infraspecific genetic variation between European and American specimens of M. prasina s. str. should be examined. These questions are currently under work and will likely be tackled in the near future. 


\section{THE SPECIES}

\section{Key to the Micarea byssacea and M. micrococca complexes in Europe}

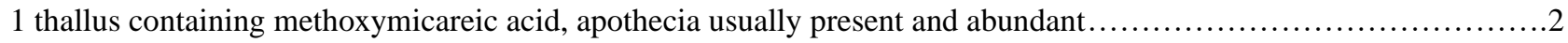

1 ' thallus and apothecia containing gyrophoric acid $(\mathrm{C}+\mathrm{red})$, apothecia usually absent or rarely few $\ldots \ldots \ldots \ldots \ldots \ldots \ldots .7$

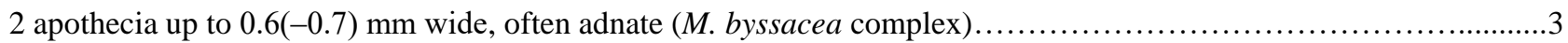

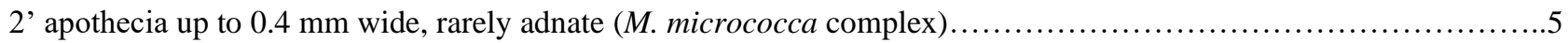

3 thallus minutely granular, olive green, apothecia usually greyish $(\mathrm{K}+$ and $\mathrm{C}+$ violet $)$

M. byssacea

3' thallus granular or areolate, vivid green, olive green, pale olive green, whitish green or sometimes partly bright green, apothecia whitish to brownish ( $\mathrm{K}-$ and $\mathrm{C}-$ )....

4 thallus usually areolate, apothecia creme white, ascospores $2.25-3 \mu \mathrm{m}$ wide.

M. microareolata

4' thallus granular and/or continuous, apothecia cream white or brownish, ascospores 3-4 $\mu \mathrm{m}$ wide M. laeta

5 thallus granular, bright green, apothecia whitish, ascospores $3-4.5 \mu \mathrm{m}$ wide. M. micrococca

5 ' thallus olive green, granular and/or continuous crust, ascospores $2-3.2(-3.5) \mu \mathrm{m}$ wide. ..6

6 thallus warted-areolate, cracked to continuous without crystalline granules, apothecia greyish tinged (K+ and $\mathrm{C}+\mathrm{violet})$, paraphyses up to $1.5 \mu \mathrm{m}$ wide. M. czarnotae

6' thallus granular with crystalline granules visible in polarized light, apothecia whitish-cream ( $\mathrm{K}^{-}$and $\left.\mathrm{C}^{-}\right)$, paraphyses of two types, up to $2.0 \mu \mathrm{m}$ wide. M. pseudomicrococca

7 thallus \pm leprose, bright green .M. viridileprosa 


\section{General notes}

For the descriptions of Micarea byssacea and M. micrococca, see Czarnota \& Guzow-Krzemińska (2010). Even with the recognition of $M$. laeta the description of $M$. byssacea is still valid. However, specimens of $M$. byssacea with completely pallid apothecia should be investigated carefully. We studied all synonyms placed under M. byssacea and M. micrococca (Czarnota 2007). Relevant conclusions are presented below species descriptions.

The mtSSU-sequences of M. byssacea and M. micrococca $\mathrm{s}$. str. used in the phylogenetic analysis (Fig. 1) are identical to those used and identified by Czarnota \& Guzow-Krzemińska (2010).

Micarea pseudomicrococca Launis \& Myllys sp. nov.

MycoBank No.: MB 824290

Thallus olive green, sometimes partly bright green, minutely granular, composed of goniocysts; apothecia abundant or few, $0.2-0.4 \mathrm{~mm}$ in diam., plane, convex or \pm hemispherical, sometimes becoming tuberculate, cream white or often pale brownish, always $\mathrm{K}-$ and $\mathrm{C}-$; ascospores oblong-ellipsoid or obovoid, $0-1(-2)$ septate, 8-14(-15) $\times$ 2.0-3.2 $\mu \mathrm{m}$; production of methoxymicareic acid. Resembles M. micrococca and M. czarnotae. Differs from M. micrococca by having olive green instead of bright green thallus and thinner ascospores. Differs from M. czarnotae by forming less numerous and crowded apothecia, lacking the Sedifoliagrey pigment and forming more granular thallus. In addition, M. pseudomicrococca has two types of paraphyses (up to $2 \mu \mathrm{m}$ wide).

Type: Finland, Etelä-Häme, Jämsä, Hallinmäki nature reserve, Betula sp. - Picea abies - dominated oldgrowth forest, on bark of decaying Betula stump, E3401759, N6894425 (YKJ), 2015, Launis 59151 (Hholotype).

GenBank accession numbers: ITS: MG521554, MG521555, MG521556. MtSSU: MG707755, MG707756, MG707757, MG707758. Mcm7: MG692516. 
(Fig. 2 A \& B)

Thallus effuse, olive green, sometimes partly bright green, minutely granular, composed of goniocysts, 25-40(-55) $\mu \mathrm{m}$ in diam., usually coalescing to form larger granules, Photobiont micareoid, algal cells 4.5$7.5 \mu \mathrm{m}$ in diam.

Apothecia abundant or few, $0.2-0.4 \mathrm{~mm}$ in diam., plane, convex or \pm hemispherical, sometimes becoming tuberculate, cream white or often pale brownish, always $\mathrm{K}^{-}$and $\mathrm{C}-$. Hypothecium hyaline. Hymenium hyaline, sometimes with vertical brownish streaks, $c$. 35-50 $\mu \mathrm{m}$ high. Epihymenium hyaline or brownish. Paraphyses numerous, of two types: 1) scanty, scarcely branched, $0.8-1.0(-1.2) \mu \mathrm{m}$ wide, apices usually not increasing; 2) thicker, 1.2-2.0 $\mu \mathrm{m}$ wide with usually increasing apices up to $3 \mu \mathrm{m}$, simple or branched, sometimes branched 1-3 times from the apices resulting in a fork- or brush-like appearance. Asci clavate, Micarea-type, 8-10 × 30-35 $\mu \mathrm{m}$. Ascospores oblong-ellipsoid or obovoid, 0-1 (-2) septate, 8-14 (-15) × 2.0-3.2 $\mu \mathrm{m}$.

Pycnidia of two types, cream white or often brownish, always $\mathrm{K}-$ and $\mathrm{C}-$. Mesopycnidia usually present and immersed in surrounding goniocysts, globose, up to $100 \mu \mathrm{m}$ in diam. Mesoconidia cylindrical or cylindrical-fusiform, 4.0-5.0 × 1.2-1.5 $\mu \mathrm{m}$. Micropycnidia usually present, sometimes few or absent, sessile or immersed, if sessile usually with gaping ostiole, $80-100 \mu \mathrm{m}$ in diam. Microconidia bacilliform to narrowly fusiform, 5.5-9.0 (-9.5) $\times 0.8-1.0(-1.2) \mu \mathrm{m}$.

Crystals (studied in polarized light) visible in hymenium and in thallus. Soluble in K

Chemistry Methoxymicareic acid.

Etymology The new species resembles morphologically a close relative Micarea micrococca. The two species differ, however, in several anatomical features and also on DNA-level.

Habitat and distribution Collected on bark of Betula sp, Prunus padus and Alnus incana, and on decaying wood of fallen Picea abies. Known so far from southern and central Finland and from Western Scotland. 
Notes. Micarea pseudomicrococca is characterized by olive green granular thallus and small cream white or pale brownish apothecia that lack the Sedifolia-grey pigment. In many respect it resembles the closely related species $M$. micrococca and $M$. czarnotae. These species are characterized by similar ecological preferences and shape and size of apothecia. In addition, all three species produce methoxymicareic acid. The main morphological characters separating Micarea pseudomicrococca from M. micrococca and M. czarnotae involve the two types of paraphyses, structure and/or color of thallus, pigmentation of apothecia and crystalline granules detectable in polarized light. Micarea micrococca forms granular thallus, very similar in structure compared to M. pseudomicrococca, but the thallus of the latter is olive green instead of bright green. In addition, M. micrococca never develops brownish or greyish apothecia, its paraphyses are thinner and of one type instead of two, and it has wider ascospores. Micarea czarnotae, on the other hand, forms numerous and often crowded apothecia and less granular thallus compared to M. pseudomicrococca. It also produces the Sedifolia-grey pigment in the apothecia, and no crystalline granules are detected in its thallus.

Additional specimens examined. -Finland: Pohjois-Karjala: Lieksa, Koli National Park, E slope of Koli, old natural forest, on wood of decaying Picea abies, N 7000159.5977, E 642051.3884 (ETRS-TM35FIN), 2013, Launis 89132 (H). Uusimaa: Mäntsälä, Ohkolanjoki, Picea abies -dominated old-growth forest, by river Ohkolanjoki near railway, on bark of standing decaying (early-stage) Alnus incana, N 6713368, E 399932 (ETRS-TM35FIN), 2013, Launis 258131 (H). - British Isles: Scotland: East Lothian (vc 82), Humbie, Church wood, on bark of Prunus padus, NT 46105, 64588, 2014, Launis 171141 \& Coppins (H).

Micarea czarnotae Launis, van den Boom, Sérusiaux \& Myllys sp. nov.

MycoBank No.: MB 824291

Thallus olive green to darkish olive green, goniocysts often coalescing to form dense \pm continuous thallus, sometimes cracked, if less developed warted-areolate; apothecia numerous, crowded, up to $0.3 \mathrm{~mm}$ in diam., 
cream-white or pale brownish, often greyish tinge (K士 violet, $\mathrm{C} \pm$ violet); ascospores oblong-ellipsoid or obovoid, $0-1$ septate, $7.0-10.0 \times 2.25-3.5 \mu \mathrm{m}$; production of methoxymicareic acid. Resembles $M$. micrococca and M. pseudomicrococca, but differs by having variously colored apothecia and by producing the Sedifoliagrey pigment. Further, M. czarnotae lacks crystalline granules in the thallus.

Type: Finland, Varsinais-Suomi, Nummi-Pusula, Myllypuro, mixed-forest between lakes Vahermanjärvi and Tarkeelanjärvi near river Myllypuro, on bark of Pinus sylvestris, in N-facing shaded and moist microhabitat, N6719586, E3335308 (YKJ), 2011, Launis 109111 (H—holotype).

GenBank accession numbers: ITS: MG521557. MtSSU: MG707759, MG707760, MG707761. Mcm7: MG692517.

(Fig. 2 C \& D)

Thallus. effuse, olive green to darkish olive green, usually \pm thick, granular, composed of goniocysts 20 $35(-40) \mu \mathrm{m}$ in diam., goniocysts usually coalescing to form dense almost continuous thallus, sometimes cracked, if less developed warted-areolate. Photobiont micareoid, algal cells 4.5-7.5 $\mu \mathrm{m}$ in diam.

Apothecia. numerous, often crowded, small, $0.1-0.3 \mathrm{~mm}$, usually plane or hemispherical, sometimes becoming tuberculate (and then up to $0.4 \mathrm{~mm}$ in diam.), cream white or brownish, often with a greyish tinge due to the Sedifolia-grey pigment ( $\mathrm{K} \pm$ violet and $\mathrm{C} \pm$ violet). Hypothecium hyaline. Hymenium hyaline, c. 30$45 \mu \mathrm{m}$ high. Epihymenium hyaline or pale grey, $\mathrm{K} \pm$ violet and $\mathrm{C} \pm$ violet. Paraphyses numerous, branched, 1.0-1.5 $\mu \mathrm{m}$ wide, apices not wider. Asci clavate, Micarea-type, 35-40 x 8-10 $\mu \mathrm{m}$. Ascospores oblong-ellipsoid or obovoid, $0-1$ septate, $7.0-10.0 \times 2.25-3.5 \mu \mathrm{m}$.

Pycnidia of two types, whitish, usually $\mathrm{K}-$ and $\mathrm{C}-$, sometimes $\mathrm{K} \pm$ violet and $\mathrm{C} \pm$ violet (the Sedifolia-grey pigment). Mesopycnidia often numerous and sessile, sometimes immersed in surrounding goniocysts, $c$. 70$100 \mu \mathrm{m}$ wide, globose or barrel-like, sometimes with gaping ostiole extruding white conidial mass. Mesoconidia cylindrical or cylindrical-fusiform, 4.0-5.0 $(-5.5) \times 1.0-1.5 \mu \mathrm{m}$. Micropycnidia immersed in surrounding goniocysts or sessile, $80-130 \mu \mathrm{m}$ wide, globose, if sessile often with gaping ostiole. Microconidia bacilliform to narrowly fusiform, $5.5-7.0 \times 0.8-1.0(-1.2) \mu \mathrm{m}$. 
Crystals (studied in polarized light) visible in hymenium, none detected in thallus. Soluble in K.

Chemistry Methoxymicareic acid.

Etymology The species is named after our colleague Dr. Pawel Czarnota for his significant contributions to the study of the genus Micarea, and for collecting the first known specimens of M. czarnotae.

Habitat and distribution Known from bark of Pinus sylvestris, wood and bark of Picea abies, bark of Quercus sp. and twigs of Alnus glutinosa. Several specimens were collected from humid environments near bog or river, or from standing tree trunks on northern side or from near ground. $M$. czarnotae is so far known from Southern Finland, Poland and the Netherlands.

Notes Micarea czarnotae was first introduced by Czarnota \& Guzow-Krzemińska (2010) as "M. micrococca B", a transitional morphotype between M. micrococca and M. byssacea. Because of the lack of clear morphological, distributional, ecological and, above all, molecular multiloci data no taxonomic innovations were proposed at that time. Our study, however, shows that M. czarnotae is both molecularly and morphologically a distinct species-level taxon.

Micarea czarnotae forms small, convex to hemispherical apothecia resembling those of M. micrococca and $M$. pseudomicrococca. However, its apothecia are often variously colored and $\mathrm{K} \pm$ violet, $\mathrm{C} \pm$ violet when the Sedifolia-grey pigment is present. It differs from M. micrococca and M. pseudomicrococca also in characters detectable in polarized light: Micarea czarnotae does not produce crystalline granules in its thallus whereas M. micrococca and M. pseudomicrococca always do.

Micarea byssacea differs in larger, often adnate apothecia and minutely granular thallus that is never densely continuous or cracked. In addition, $M$. byssacea produces crystalline granules in thallus and hymenium detectable in polarized light.

Additional specimens examined. —Finland: Uusimaa: Tuusula, near Korso, Picea abies dominated managed forest, shaded and dense, on wood of fallen decaying (late-stage) Picea abies, N 6692506, E 391428 (ETRSTM35FIN), 2013, Launis 1010133 (H). - Netherlands: Noord-Brabant, W of Son, S of Bestseweg, 
51 $30^{\circ} 39^{\prime \prime} \mathrm{N} / 05^{\circ} 27^{\prime} 41^{\prime \prime E}, 30 \mathrm{~m}$ alt., small Pinus forest, on fallen rotting trunk, 2014, P. \& B. van den Boom 50312 (LG, hb v.d. Boom).—Poland: Kotlina Sandomierska: Płaskowyż Kolbuszowski, c. 2 km SE of Wilcza Wola village, $50^{\circ} 19^{\prime} 69^{\prime \prime} \mathrm{N} / 21^{\circ} 58^{\prime} 23^{\prime \prime} \mathrm{E}$, c. $120 \mathrm{~m}$. alt., on bark of Pinus sylvestris within wet pine forest, 2003, Czarnota 3632 (GPN). Wzniesienia Lódzkie: Wzniesienia Łódzkie Landscape Park, Tadzin forest

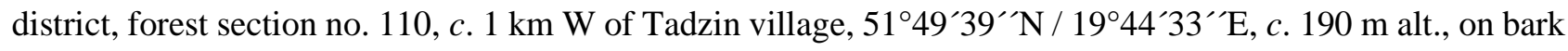
of Quercus sp. within mixed pine-oak forest, 2004, Czarnota 4179 (GPN). Pojezierze Chetmińsko-Dobrzyńskie, Garb Lubawski: Park Krajobrazowy Wzgórz Dylewskich, oddz. 97c., on twigs of Alnus glutinosa within alder bog forest, (no coordinates available), 2002, Czarnota 3179 (GPN) \& Kukwa. Beskid Niski Mts: SW slope of Piotruś Mt., above Stasianie settlement in valley Jasiolka river, $49^{\circ} 28^{\prime} 02^{\prime \prime} \mathrm{N} / 21^{\circ} 44^{\prime} 20^{\prime \prime} \mathrm{E}, c .500 \mathrm{~m}$ alt., on bark at the base of Picea abies trunk within Carpathian beech forest, 2004, Czarnota 4059 (GPN).

Micarea microareolata Launis, Pykälä \& Myllys sp. nov.

MycoBank No.: MB 824292

Thallus pale olive green, whitish green or bright green, goniocysts usually coalescing to form convex to subglobose small areolae; apothecia numerous, whitish or cream white, up to $0.6(-0.7) \mathrm{mm}$ in diam., adnate, convex to hemispherical, $\mathrm{K}-$ and $\mathrm{C}-$; ascospores oblong-ellipsoid or obovoid, $0-1$ septate, $7.5-12.0 \times(2.0-)$ 2.25-3.0 $\mu \mathrm{m}$; production of methoxymicareic acid. Resembles $M$. byssacea and M. laeta but differs from $M$. byssacea by lacking the Sedifolia-grey pigment, forming more aggregated thallus and thinner ascospores. $M$. laeta has also pale apothecia, but its spores are wider than those of M. microareolata.

Type: Finland, Etelä-Savo, Jyväskylä, Korpilahti, Picea abies -dominated mixed managed forest, on bark of standing decaying Picea abies, E3418403, N6885234 (YKJ), 2015, Launis 59152 (H-holotype).

GenBank accession numbers: ITS: MG521558, MG521559, MG521560, MG521561. MtSSU: MG707762, MG707763, MG707764, MG707765, MG707766, MG707767. Mcm7: MG692518, MG692519, MG692520, MG692521, MG692522, MG692523, MG692524, MG692525, MG692526.

(Fig. 2 E \& F) 
Thallus effuse, pale olive green, whitish green or sometimes partly bright green, usually rather thin, composed of goniocysts $18-40 \mu \mathrm{m}$ in diam., goniocysts usually coalescing to form convex to subglobose small areolae (in cross section goniocysts distinctly visible), areolae effuse or concentrated, sometimes thallus granular or if less developed small warted. Photobiont micareoid, algal cells 4.5-7.5 $\mu \mathrm{m}$ in diam.

Apothecia usually numerous, whitish cream, 0.3-0.6 (-0.7) mm, adnate, convex to hemispherical, sometimes becoming tuberculate, always $\mathrm{K}^{-}$and $\mathrm{C}-$. Hypothecium hyaline. Hymenium hyaline, $c .30-45 \mu \mathrm{m}$ high. Epihymenium hyaline. Paraphyses numerous, richly branched, 1.0-1.8 (-2) $\mu \mathrm{m}$ wide, apices not wider or only slightly. Asci clavate, Micarea-type, 25-35 × 9-10 $\mu \mathrm{m}$. Ascospores oblong-ellipsoid or obovoid, 0-1 septate, $7.5-12.0 \times(2.0-) 2.2-3.0 \mu \mathrm{m}$.

Pycnidia of two types, small and inconspicuous, whitish, $\mathrm{K}^{-}$and $\mathrm{C}^{-}$. Mesopycnidia usually present, immersed in surrounding goniocysts, up to $70 \mu \mathrm{m}$ wide, sometimes sessile with gaping ostiole extruding white conidial mass. Mesoconidia cylindrical or cylindrical-fusiform, $4.0-5.5 \quad(-6.0)$ x $1.0-1.2(-1.5) \mu \mathrm{m}$. Micropycnidia immersed in surrounding goniocysts, globose, up to $60 \mu \mathrm{m}$ wide. Microconidia bacilliform to narrowly fusiform, straight or slightly curved, $5-7.5 \times 0.8-1 \mu \mathrm{m}$.

Crystals (studied in polarized light) visible in hymenium and in thallus. Soluble in K.

Chemistry Methoxymicareic acid.

Etymology The name Micarea microareolata refers to the areolate morphology of the thallus.

Habitat and distribution Micarea microareolata is known from bark of Alnus glutinosa, Betula sp., Picea abies, Salix pentandra and Quercus robur from southern and central Finland and southern Sweden. M. microareolata seems to have rather broad habitat requirements. The specimens have been collected from welllit to shaded and from mesic to wet, managed and old-growth forests.

Notes Micarea microareolata is characterized by \pm pale green areolate thallus, composed of goniocysts, and cream white apothecia that lack the Sedifolia-grey pigment. In many respect it resembles M. byssacea and M. laeta, with which it forms a closely related species group. These three species are characterized by similar 
ecological preferences and shape and size of the apothecia. In addition, all three species produce methoxymicareic acid and crystalline granules in the apothecia and thallus.

The main morphological features separating Micarea microareolata from M. byssacea and M. laeta involve the structure of thallus, pigmentation in apothecia and spore size. Micarea byssacea usually produces the Sedifolia-grey pigment in apothecia, unless when growing in deep shade. In addition, it forms minutely granular thallus that is never areolate, and wider ascospores. Micarea laeta, on the other hand, develops pale apothecia that are similar to $M$. microareolata. However, M. microareolata has narrower spores and an areolate thallus.

In the phylogeny Micarea microareolata forms two subgroups differing by few base pairs. The two subgroups show no morphological, chemical or ecological differences. In addition, rather large amount of missing data is present especially in the ITS-regions of the other subgroup. Therefore, at least for now, we treat these groups as one species instead of e.g. two closely related cryptic species.

Additional specimens examined. —Finland: Varsinais-Suomi: Lohja, Ojamo, Ojamo lime quarry $200 \mathrm{~m}$ west., Alnus glutinosa - Salix dominated swamp on shore of lake Lohjanjärvi, on Salix pentandra, 33 m a.s.l.,

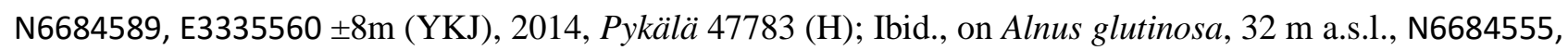
E3335588 +8m (YKJ), 2014, Pykälä 47787 (H). Pohjois-Karjala: Lieksa, Koli National Park, E slope of Koli, old natural forest, on bark of fallen decaying (late stage) Picea abies, N7000213.0560, E641998.5098 (ETRSTM35FIN), 2013, Launis 59133 (H); Ibid., on bark of decaying (late stage) Betula sp., N7000159.5977, E642051.3884 (ETRS-TM35FIN), 2013, Launis 89133 (H). Etelä-Savo, Joutsa, Höystösensuo, Pinus sylvestris -dominated mixed managed forest, on bark of standing decaying Picea abies, E3459820, N6867631(YKJ), 2015, Launis 186151 (H). Varsinais-Suomi: Lohja, Pappila, Tytyri lime quarry $150 \mathrm{~m}$ E, shore forest of lake Lohjanjärvi, Alnus-dominated, on dead Alnus glutinosa, 32 m a.s.1., N6687374, E3338195 \pm 8 m (YKJ), 2015, Pykälä 47948 (H). —Sweden: Östergötland: Vadstena region, Omberg, near top of Hjässan, well-lit forest, on bark of Quercus robur, 58 $18^{\prime} 24,1^{\prime \prime} \mathrm{N}, 1^{\circ} 38^{\prime} 55,2^{\prime \prime} \mathrm{E}, 262.8 \mathrm{~m}$ a.s.1., 2013, Launis 148131, $148132(\mathrm{H})$. 


\section{Micarea laeta Launis \& Myllys sp. nov.}

\section{MycoBank No.: MB 824294}

Thallus effuse, vivid green to olive green, composed of goniocysts, granular or almost continuous crust, if less developed small warted; apothecia numerous, usually creme white, sometimes brownish, up to $0.5(-0.6) \mathrm{mm}$, adnate, convex to hemispherical, rarely subglobose, simple or tuberculate; ascospores oblong-ellipsoid or obovoid, $0-1$ sept., (8.0-) 8.5-12.0 × 3.0-4.0 $\mu \mathrm{m}$; production of methoxymicareic acid. Resembles Micarea byssacea and M. microareolata, but differs from M. byssacea by lacking the Sedifolia-grey pigment and often forming more aggregated or continuous thallus. Micarea microareolata, on the other hand, has narrower spores and usually an areolate thallus.

Type: Finland, Etelä-Häme, Jyväskylä, Korpilahti, Picea abies -dominated mixed managed forest, on bark of standing decaying Betula sp., on shaded N-side of the tree, E3418597, N6885262 (YKJ), 5.9.2015, Launis 59153a (H—holotype); 59153b (E—isotype).

GenBank accession numbers: ITS: MG521565, MG521566, MG521567, MG521568, MG521569, MG521570. MtSSU: MG707771, MG707772, MG707773, MG707774, MG707775, MG707776, MG707777, MG707778, MG707779, MG707780, MG707781. Mcm7: MG692530, MG692531, MG692532, MG692533, MG692534, MG692535, MG692536, MG692537, MG692538, MG692539, MG692540, MG692541.

(Fig. $2 \mathrm{G} \& \mathrm{H}$ )

Thallus effuse, vivid green to olive green, usually rather thin, composed of goniocysts $17-40 \mu \mathrm{m}$ in diam., goniocysts usually coalescing to form larger granules or almost a continuous crust, if less developed small warted. Photobiont micareoid, algal cells $4.5-7.5 \mu \mathrm{m}$ in diam.

Apothecia numerous, whitish or usually cream white, sometimes brownish, $0.3-0.5(-0.6) \mathrm{mm}$, adnate, convex to hemispherical, rarely subglobose, simple or becoming tuberculate (and then up to $0.6 \mathrm{~mm}$ in diam.), always $\mathrm{K}-$ and $\mathrm{C}-$. Hypothecium hyaline. Hymenium hyaline $c .35-50 \mu \mathrm{m}$ high. Epihymenium hyaline. 
Paraphyses numerous, branched, 1.0-1.5 (-1.8) $\mu \mathrm{m}$ wide, apices scarcely wider. Asci clavate, Micarea-type, $35-40 \times 8-10 \mu \mathrm{m}$. Ascospores oblong-ellipsoid or obovoid, 0-1 septate, $(8.0-)$ 8.5-12.0 × 3.0-4.0 $\mu \mathrm{m}$.

Pycnidia of two types, whitish, $\mathrm{K}-$ and $\mathrm{C}-$. Mesopycnidia usually numerous, globose or barrel-like, 40-90 $\mu \mathrm{m}$ wide, usually immersed in surrounding goniocysts, sometimes sessile with gaping ostiole and extruding white conidial mass. Mesoconidia cylindrical or cylindrical-fusiform, 4.0-5.5 × 1.2-1.5 $\mu \mathrm{m}$. Micropycnidia immersed in surrounding goniocysts, inconspicuous, globose, up to $60 \mu \mathrm{m}$ wide. Microconidia bacilliform to narrowly fusiform, straight or slightly curved, 5-7.5 (-8.0) $\times 0.8-1 \mu \mathrm{m}$.

Crystals (studied in polarized light) visible in hymenium and in thallus. Soluble in K.

Chemistry Methoxymicareic acid.

Etymology The name is derived from Malme's exsiccate specimen Micarea prasina Fr. f. laeta Th. Fr. The original etymology chosen by Th. Fries refers to the pale apothecia.

Habitat and distribution Known from bark of Betula sp. and bark and wood of Picea abies. So far known from several localities in southern and central Finland, and Sweden. Specimens were collected from managed and old-growth forests.

Notes Specimens referring to the newly described species Micarea laeta have been collected many times since 1890 and determined as a form level of M. prasina, i.e. M. prasina f. laeta (Th. Fr.) Hedl (=Catillaria prasina f. laeta Th. Fr.) (Hedlund 1892) or treated as a synonym of M. prasina Fr. (Coppins 1983) and of $M$. byssacea (Czarnota \& Guzow-Krzemińska 2010). In light of this, specimens resembling M. byssacea with completely pallid apothecia should be investigated carefully.

Because Micarea laeta was first known as a form of M. prasina we considered describing a new combination instead of a new species. However this was not possible because the original name has been shown invalid (see Coppins 1983), because the type specimen of M. prasina a laeta is the same as that of M. prasina. The taxon is found e.g. in Malme's exsiccate specimens and based on phenotypic characters this specimen is identical to the fresh specimens found in our study. Therefore we propose the name M. laeta for the new species. 
To our best knowledge the name 'laeta' has previously only been used invalidly in the level of form of $M$. prasina, and never on species level. Our molecular results clearly show that the taxon we have found and linked to the Malme's exsiccate is actually a species level unit. As the word 'laeta' refers to pale, we see it very suitable for the new species with pale apothecia.

Micarea laeta is characterized by a granular thallus, pale apothecia and wide ascospores. The main morphological features separating M. laeta from M. byssacea and M. microareolata involve the structure of thallus, pigmentation in apothecia and spore width. Micarea byssacea usually produces the Sedifolia-grey pigment in apothecia, unless when growing in deep shade. In addition, it forms minutely granular thallus that is rarely coalescing to form larger granules, or a continuous crust. Micarea microareolata, on the other hand, has narrower spores and usually an areolate thallus.

Exsiccati. Malme, Lichenes suecici exsiccati, N:o 23 (H) [as Micarea prasina Fr. f. laeta Th. Fr; Sweden, Södermanland, 1890, O. Malme]. Magnusson, Lichenes Selecti Scandinavici Exsiccati, N:o 134 (H) [as Catillaria prasina (Fr.) Th. Fr. f. laeta Th. Fr; Sweden, Västergötland, 1927, A. H. Magnusson].

Additional specimens examined. —Finland: Etelä-Häme: Hämeenlinna, Evo, managed mixed forest, on bark of fallen decaying Picea abies, N6787475.7690, E399873.8954 (ETRS-TM35FIN9) 2013, Launis 1510131 (H). Etelä-Häme: Jyväskylä, Korpilahti, Picea abies -dominated mixed managed forest, on bark of standing decaying Betula sp., on shaded N-side of the tree, E3418597, N6885262 (YKJ), 2015, Launis 59153 (H). Pohjois-Häme: Jyväskylä, Kuusimäki, mixed managed forest, on bark of standing decaying (early stage) Picea abies, E3425022, N6902706 (YKJ), 2015, Launis 49151 (H). Ibid., Picea abies -dominated mixed managed forest, on bark of standing decaying Picea abies, E3418599, N6885222 (YKJ), 2015, Launis 59154, 59155 (H). Ibid., mixed managed forest, on bark of standing decaying Betula sp., in shade near ground, E3425062, N6902944 (YKJ), 2015, Launis 49152 (H). Etelä-Savo: Joutsa, Höystösensuo, Pinus sylvestris -dominated mixed managed forest, on bark of standing decaying Picea abies, N6867631, E3459820 (YKJ), 2015, Launis 186152 (H). Etelä-Savo: Joutsa, Leivonmäki, managed mixed forest, on bark of standing decaying Betula sp, 
in shade, E3443740, N6868132 (YKJ), 2014, Launis 269141, (H). Etelä-Savo: Äänekoski, managed mixed forest, on bark of standing decaying Picea abies, N-side of the tree in shade, E3427400, N6959860 (YKJ), 2015, Launis 286151 (H). Uusimaa: Tuusula, near Korso, Picea abies dominated managed forest, shaded and dense, on wood of fallen decaying (mid-stage) Picea abies, N 6692506, E 391428 (ETRS-TM35FIN), 2013, Launis 1010133, 1010134, $1010135(\mathrm{H})$.

\section{ACKNOWLEDGEMENTS}

We wish to thank two anonymous reviewers for their insightful comments that improved the text. We also warmly thank Dr. Teuvo Ahti for his valuable help with the nomenclature. Financial support for this study was provided by the research project "Conservation of wood-inhabiting Ascomycetes in changing forest landscapes" (grant number 7000T-YTB079), part of the research program on deficiently known and threatened forest species (PUTTE) financed by the Ministry of the Environment.

\section{LEGENDS}

TABLE 1. List of specimens used in the phylogenetic analyses. New species and new sequences generated for the current study are in bold.

\begin{tabular}{|c|c|c|c|c|c|}
\hline \multirow[t]{2}{*}{ Specimens } & \multirow[t]{2}{*}{ Locality } & \multirow[t]{2}{*}{$\begin{array}{l}\text { Collector, collection number, DNA sample } \\
\text { number (where appropriate), herbarium }\end{array}$} & \multicolumn{3}{|c|}{ GenBank accession number } \\
\hline & & & ITS & mtSSU & Mcm7 \\
\hline Micarea peliocarpa & USA & Launis 66123, DNA A324, (H) & MG5 & MG707741 & MG692505 \\
\hline M. adnata & Norway & Andersen 48 (BG) & - & AY567751 & - \\
\hline M. byssacea & Finland & Launis 289103, DNA A98, (H) & MG5 & MG707768 & MG692527 \\
\hline M. byssacea & Finland & Launis 289102, DNA A97, (H) & MG5 & MG707769 & MG692528 \\
\hline M. byssacea & Finland & Launis 289101, DNA A96, (H) & MG5 & MG707770 & MG692529 \\
\hline M. czarnotae & Poland & Czarnota 3632 (GPN) & - & EF453668 & - \\
\hline M. czarnotae & Poland & Czarnota 4179 (GPN) & - & EF453691 & - \\
\hline M. czarnotae & Poland & Czarnota 3179 (GPN) & - & EF453674 & - \\
\hline M. czarnotae & Poland & Czarnota 4059 (GPN) & - & EF453663 & - \\
\hline
\end{tabular}




\begin{tabular}{|c|c|c|c|c|c|}
\hline M. czarnotae & Finland & Launis 109111, DNA A604, (H) & - & MG707759 & - \\
\hline M. czarnotae & Finland & Launis 1010133, DNA A455, (H) & MG521557 & MG707760 & MG692517 \\
\hline M. czarnotae & Belgium & P. van den Boom 50312, DNA 3712, (LG) & - & MG707761 & - \\
\hline M. elachista & Finland & Launis 67113, DNA A340, (H) & MG521548 & 3 MG707745 & - \\
\hline M. globulosella & Finland & Launis 67112, DNA A240, (H) & MG521546 & MG707743 & MG692507 \\
\hline M. globulosella & Finland & Launis 67114, DNA A243, (H) & MG521547 & MG707744 & MG692508 \\
\hline M. hedlundii & Finland & Launis 67119, DNA A254, (H) & MG521551 & MG707749 & MG692512 \\
\hline M. herbarum & Netherlands & Brand 63193 (LG) & - & KX459350 & - \\
\hline M. herbarum & Netherlands & P. \& G. van den Boom 52575 (LG) & - & KX459349 & MG692513 \\
\hline M. laeta & Finland & Launis 59153, DNA A825, (H) & MG521565 & MG707771 & MG692530 \\
\hline M. laeta & Finland & Launis 49151, DNA A819, (H) & MG521566 & MG707772 & MG692531 \\
\hline M. laeta & Finland & Launis 59154, DNA A824, (H) & MG521567 & MG707773 & MG692532 \\
\hline M. laeta & Finland & Launis 59155, DNA A827, (H) & - & MG707774 & MG692533 \\
\hline M. Iaeta & Finland & Launis 49152, DNA A823, (H) & - & MG707775 & MG692534 \\
\hline M. laeta & Finland & Launis 186152, DNA A803, (H) & - & - & MG692535 \\
\hline M. laeta & Finland & Launis 269141, DNA A806, (H) & - & MG707776 & MG692536 \\
\hline M. laeta & Finland & Launis 286151, DNA A816, (H) & - & MG707777 & MG692537 \\
\hline M. laeta & Finland & Launis 1010133, DNA A477, (H) & MG521568 & MG707778 & MG692538 \\
\hline M. laeta & Finland & Launis 1010134, DNA A478, (H) & MG521569 & MG707779 & MG692539 \\
\hline M. laeta & Finland & Launis 1510131, DNA A762, (H) & - & MG707780 & MG692540 \\
\hline M. laeta & Finland & Launis 1010135, DNA A427, (H) & MG521570 & MG707781 & MG692541 \\
\hline M. microareolata & Sweden & Launis 148131, DNA A393, (H) & MG521558 & MG707762 & MG692518 \\
\hline M. microareolata & Sweden & Launis 148132, DNA A394, (H) & MG521559 & MG707763 & MG692519 \\
\hline M. microareolata & Finland & Launis 59152, DNA A826, (H) & MG521560 & MG707764 & MG692520 \\
\hline M. microareolata & Finland & Pykälä 47783, DNA A798, (H) & - & - & MG692521 \\
\hline M. microareolata & Finland & Pykälä 47787, DNA A797, (H) & - & MG707765 & MG692522 \\
\hline M. microareolata & Finland & Launis 59133, DNA A565, (H) & MG521561 & MG707766 & MG692523 \\
\hline M. microareolata & Finland & Launis 89133, DNA A629, (H) & - & MG707767 & MG692524 \\
\hline M. microareolata & Finland & Launis 186151, DNA A802, (H) & - & - & MG692525 \\
\hline M. microareolata & Finland & Pykälä 47948, DNA A801, (H) & - & - & MG692526 \\
\hline M. micrococca & Finland & Launis 299101, DNA A100, (H) & MG521552 & MG707753 & MG692514 \\
\hline M. micrococca & USA & Launis 146127, DNA A320, (H) & MG521553 & MG707754 & MG692515 \\
\hline M. misella & Finland & Launis 108111, DNA A264, (H) & MG521545 & MG707742 & MG692506 \\
\hline M. nowakii & Finland & Launis 245131, DNA A684, (H) & - & MG707751 & - \\
\hline M. nowakii & Poland & Czarnota \& Guzow-Krzemińska & - & EF453688 & - \\
\hline
\end{tabular}




\begin{tabular}{|c|c|c|c|c|c|}
\hline M. prasina & Finland & Launis 265101, DNA A92, (H) & MG521549 & MG707747 & MG692510 \\
\hline M. prasina & Finland & Launis 199105, DNA A93, (H) & MG521550 & MG707748 & MG692511 \\
\hline M. prasina & USA & Tønsberg 30856 (BG) & - & AY756452 & - \\
\hline M. pseudomicrococca & Finland & Launis 59151, DNA A811, (H) & MG521554 & MG707755 & - \\
\hline M. pseudomicrococca & Finland & Launis 89132, DNA A599, (H) & MG521555 & MG707756 & - \\
\hline M. pseudomicrococca & Finland & Launis 258131, DNA A603, (H) & - & MG707757 & - \\
\hline M. pseudomicrococca & Scotland & Launis 171141, DNA A645, (H) & MG521556 & MG707758 & MG692516 \\
\hline M. pycnidiophora & USA & Tønsberg 30881 (BG) & - & AY567754 & - \\
\hline M. soralifera & Poland & Kukwa 13001 (GPN) & KT119887 & KT119886 & - \\
\hline M. soralifera & Finland & Launis 1710131, DNA A714, (H) & - & MG707746 & MG692509 \\
\hline M. sp. Lineage A & Scotland & Launis 171142 , DNA A648, (H) & MG521571 & MG707782 & MG692542 \\
\hline M. stipitata & USA & Ekman s.n. & - & AY567753 & - \\
\hline M. subviridescens & Scotland & Czarnota 3599 (GPN) & - & EF453666 & - \\
\hline M. synotheoides & Norway & Andersen 47 (BG) & - & AY567756 & - \\
\hline M. tomentosa & Finland & Launis 11013, DNA A773, $(\mathrm{H})$ & - & MG707750 & - \\
\hline M. tomentosa & Poland & Czarnota 3949 (GPN) & - & EF453686 & - \\
\hline M. viridileprosa & Poland & Czarnota 3436 (GPN) & - & EF453671 & - \\
\hline M. viridileprosa & Poland & Czarnota 3869 (GPN) & - & EF453673 & - \\
\hline M. xanthonica & USA & Tønsberg 25674 (BG) & - & AY756454 & - \\
\hline
\end{tabular}




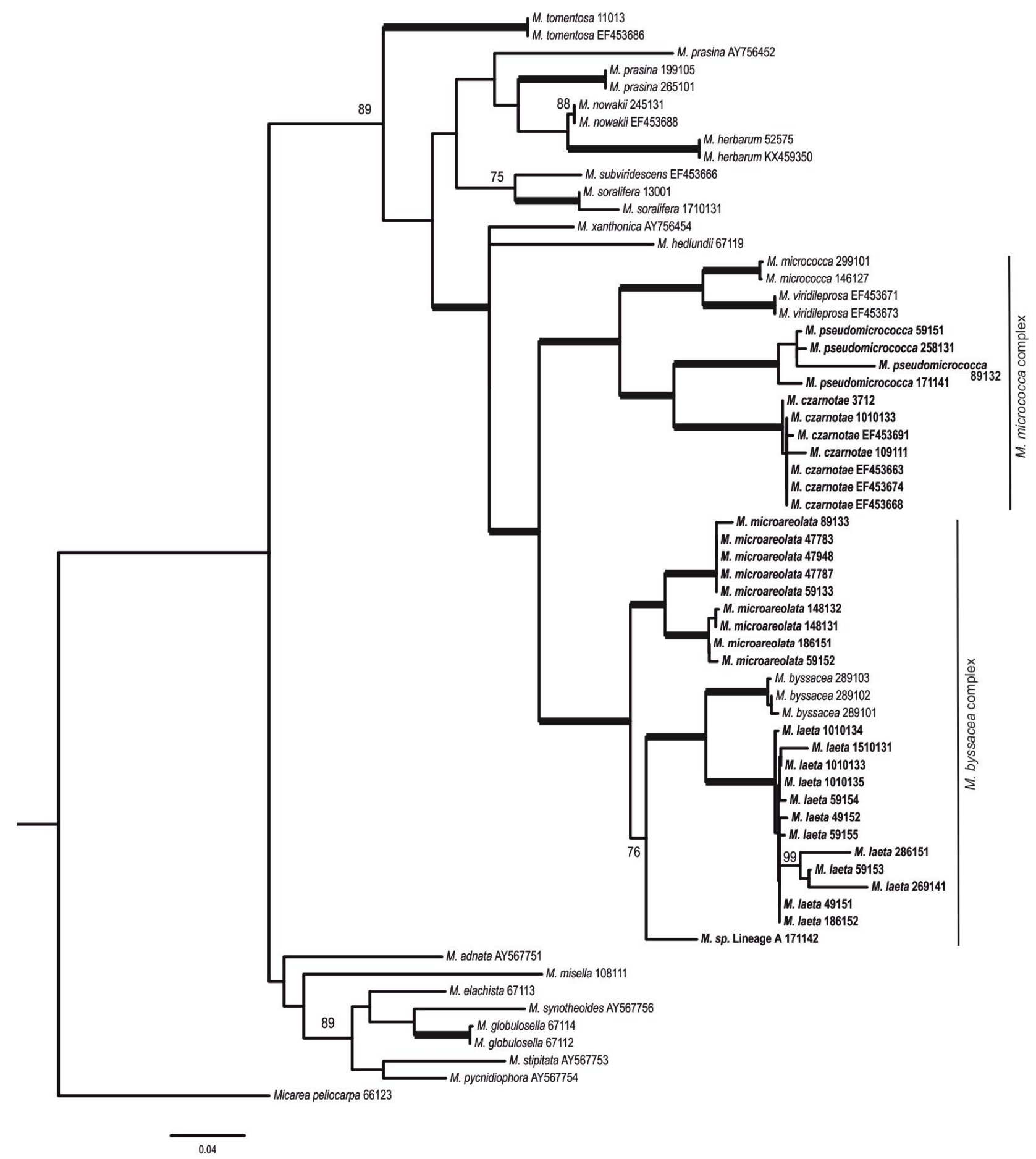

FIG. 1. Phylogenetic relationships of Micarea pseudomicrococca sp. nov., M. czarnotae sp. nov., M. microareolata sp. nov., M. laeta sp. nov. and M. sp. - lineage A (shown in bold). A maximum likelihood phylogram obtained from RAxML analysis based on the combined ITS, mtSSU and $M c m 7$ data set. Branches supported with bootstrap values $\geqslant 75 \%$ in both analyses (RAxML and TNT) are indicated in bold. Bootstrap values $\geqslant 75 \%$ only supported in maximum likelihood analysis are shown above nodes. 
FIG. 2. A \& B, Micarea czarnotae (holotype); A, habitus; B, apothecial section. C \& D, M. laeta (holotype); C, habitus; D, apothecial section. E \& F, M. microareolata (Pykälä 47787, H); E, habitus; F, apothecial section. G \& H, M. pseudomicrococca (holotype); G, habitus; H, apothecial section. Scale bars: A, C, E \& G=1 mm; $\mathrm{B}, \mathrm{D}, \mathrm{F} \& \mathrm{H}=100 \mu \mathrm{m}$

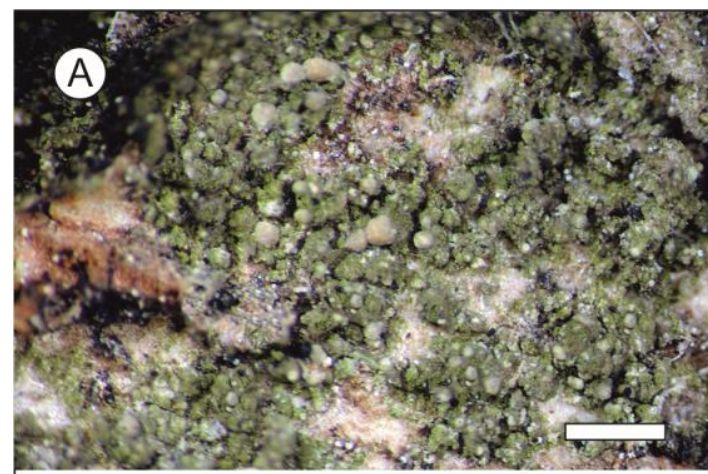

(B)

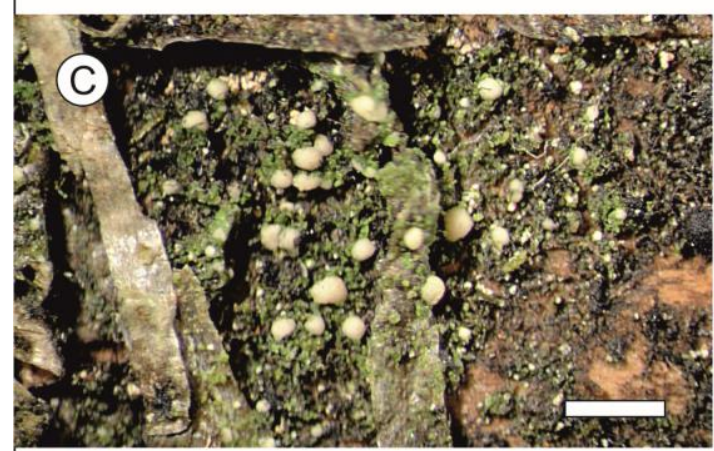

(D)
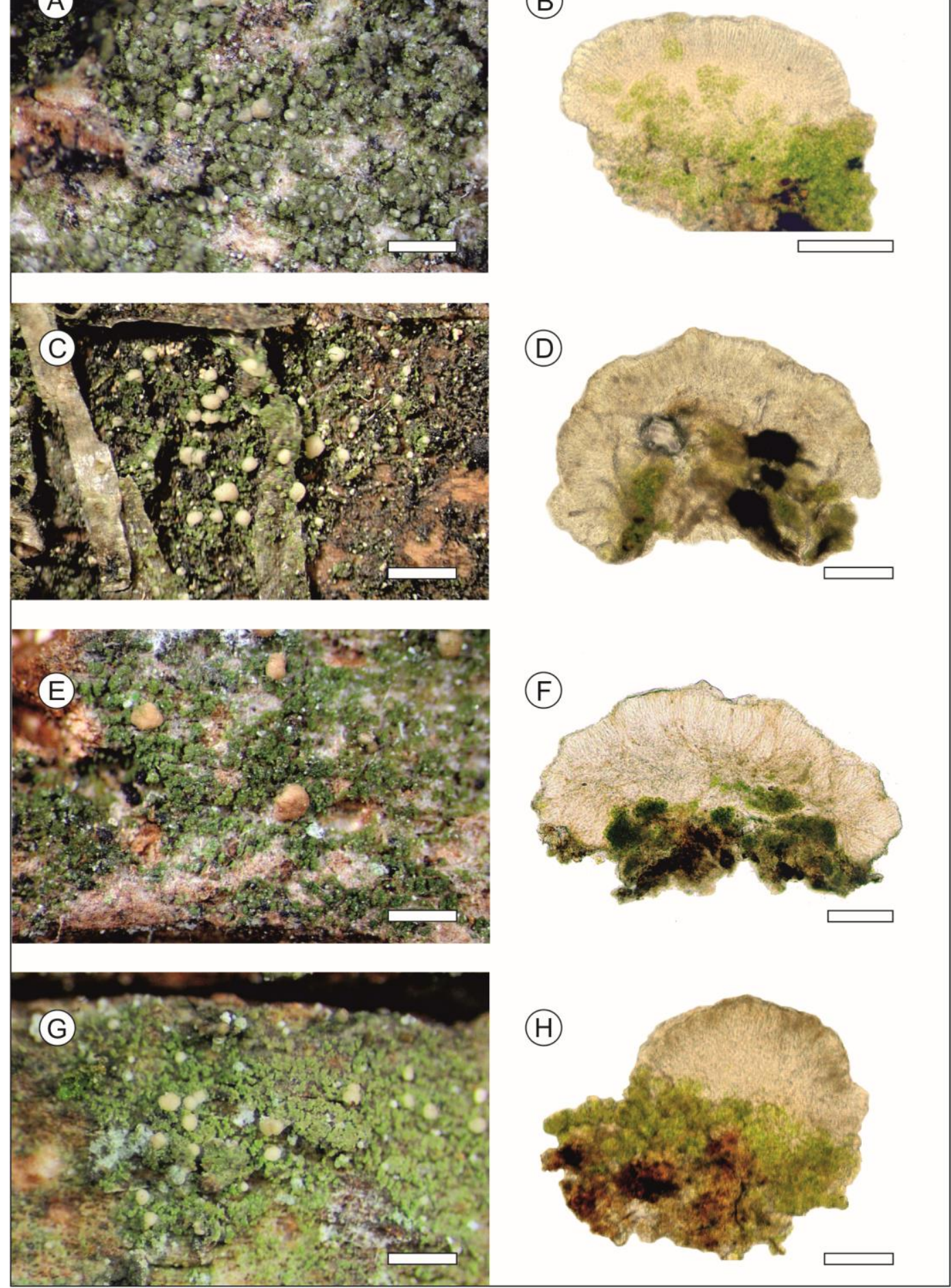
FIG. 3. A, Micarea byssacea (Launis 66128, H) habitus; B, M. micrococca s.s. (Launis 1010131, H) habitus; C, M. prasina s.str. (Launis 229106, H) habitus; D, Micarea sp. lineage A (Launis 171142, H, see Fig. 1) habitus. Scale bars $=1 \mathrm{~mm}$.
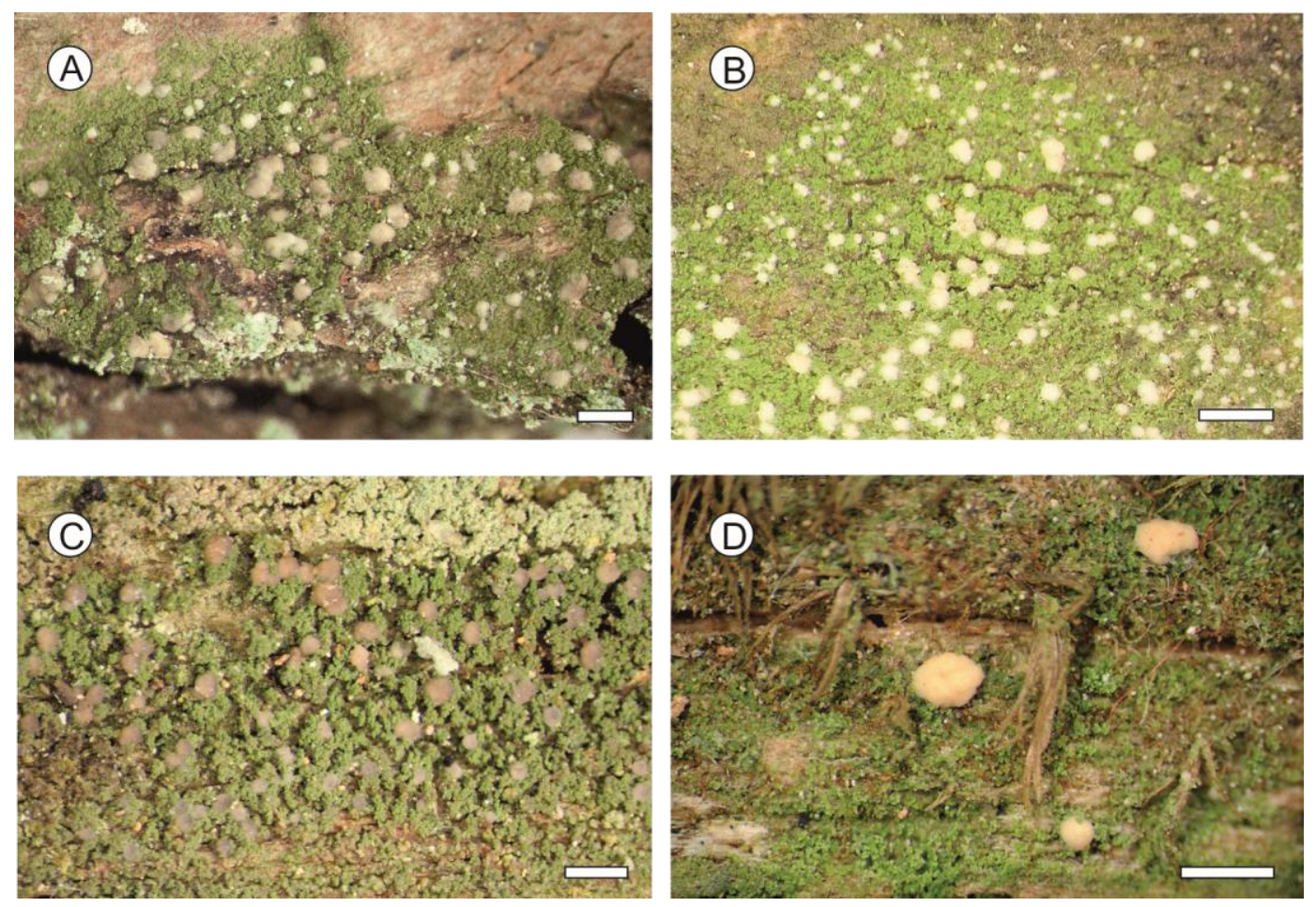
FIG. 4. Crystalline granules in apothecial sections, detected in polarized light. A, Micarea czarnotae (holotype); B, M. laeta (holotype); C, M. microareolata (holotype); D, M. prasina (Launis 229106, H); E, M. pseudomicrococca (holotype). Scale bars $=100 \mu \mathrm{m}$.
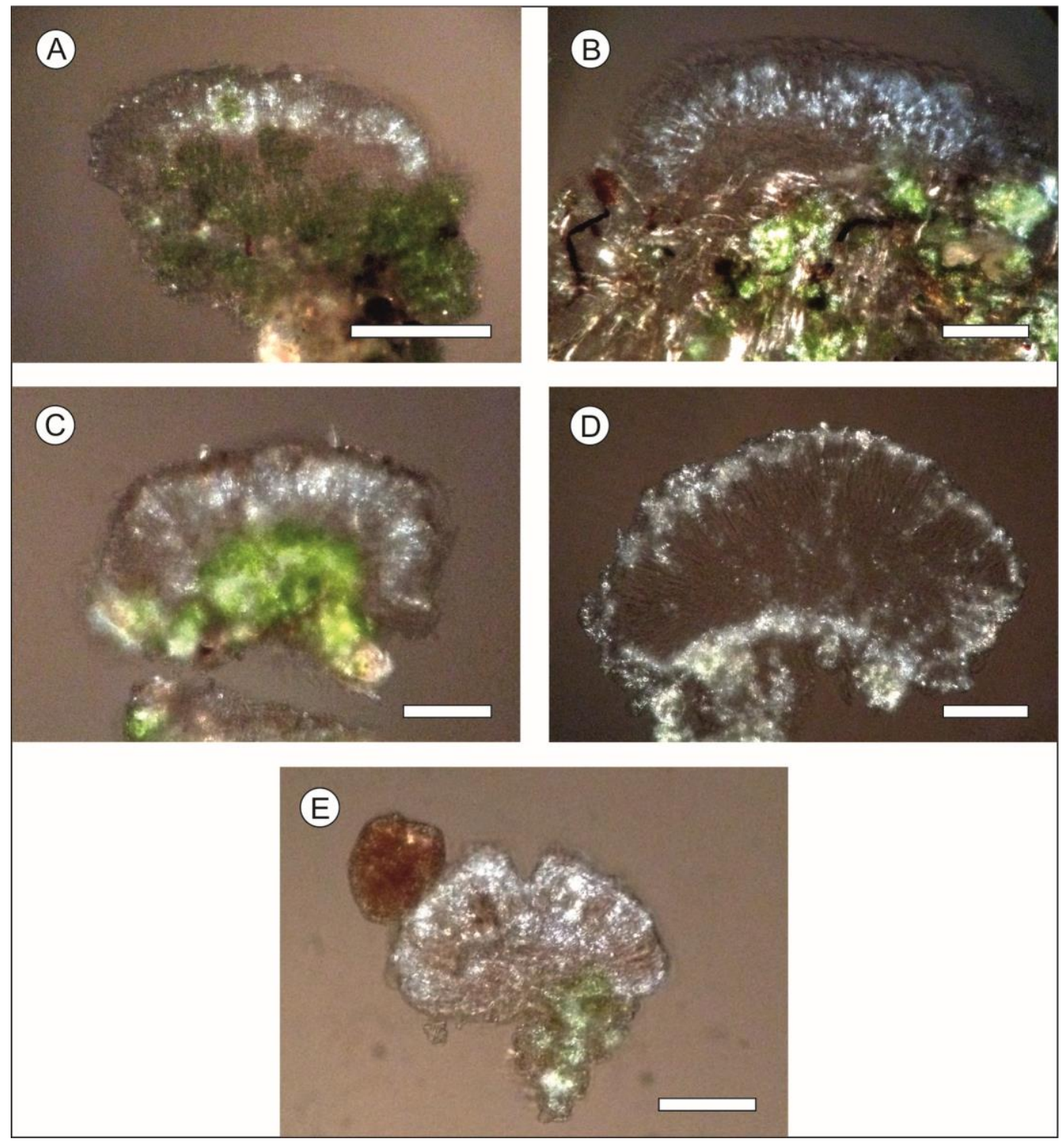


\section{REFERENCES}

Andersen, H. L. (2004) Phylogeny and classification of Micarea. Ph.D thesis, University of Bergen, Norway.

Andersen, H. L. \& Ekman, S. (2005) Disintegration of the Micareaceae (lichenized Ascomycota): a molecular phylogeny based on mitochondral rDNA sequences. Mycological Research 109: 21-30.

Aptroot, A. \& Cácares, M. E. S. (2014) New lichen species from termite nests in rainforest in Brazilian Rondônia and adjacent Amazonas. Lichenologist 46: 365-372.

Barton, J. \& Lendemer, J. C. (2014) Micarea micrococca and M. prasina, the first assessment of two very similar species in eastern North America. The Bryologist 117: 223-231.

Brand, A. M., van den Boom, P. P. G. \& Sérusiaux, E. (2014) Unveiling a surprising diversity in the lichen genus Micarea (Pilocarpaceae) in Réunion (Mascarenes archipelago, Indian Ocean). Lichenologist 46: 413-439.

Brodo, I. M. (1984) The North American species of the Lecanora subfusca group. Nova Hedwigia 79: 63185.

Cáceres, M. E. S., Mota, D. A., de Jesus, L. S. \& Aptroot, A. (2013) The new lichen species Micarea corallothallina from Serra da Jibóia, an Atlantic rainforest enclave in Bahia, NE Brazil. Lichenologist 45: $371-373$.

Córdova-Chávez, O., Aptroot, A., Castillo-Camposa, G., Cácares, M. E. S. \& Pérez-Pérez, R. E. (2014) Three new lichen species from cloud forest in Veracuz, Mexico. Cryptogamie, Mycologie 35: 157-162.

Coppins, B. J. (1983) A taxonomic study of the lichen genus Micarea in Europe. Bulletin of the British Museum (Natural History), Botany series 11: 17-214.

Coppins, B. J. \& Tønsberg, T. (2001) A new xanthone-containing Micarea from Northwest Europe and the Pacific Northwest of North America. Lichenologist 33: 93-96.

Coppins, B. J. (2002) Checklist of lichens of Great Britain and Ireland 86. 2002 London: British Lichen Society. 
Coppins, B. J. (2009) Micarea Fr. (1825) In: The Lichens of Great Britain and Ireland (C. W. Smith, A. Aptroot, B. J. Coppins, A. Fletcher, O. L. Gilbert, P. W. James \& P. A. Wolseley, eds): 583-606. London: British Lichen Society.

Culberson, C. F. \& Kristinsson, H. D. (1970) A standardized method for the identification of lichen products. Journal of Chromatocraphy A 46: 85-93.

Czarnota, P. (2007) The lichen genus Micarea (Lecanorales, Ascomycota) in Poland. Polish Botanical Studies 23: $1-190 p$.

Czarnota, P. \& Guzow-Krzemińska, B. (2010) A phylogenetic study of the Micarea prasina group shows that Micarea micrococca includes three distinct lineages. Lichenologist 42: 7-21.

Edgar, R. C. (2004) MUSCLE: multiple sequence alignment with high accuracy and high throughput. Nucleic acids research 32: 1792-1797.

Ekman, S. \& Svensson, M. (2014) Brianaria (Psoraceae), a new genus to accommodate the Micarea sylvicola group. Lichenologist 46: 285-294.

Goloboff, P., Farris, J. \& Nixon, K. (2008) TNT, a free program for phylogenetic analysis. Cladistics 24: 774786.

Guzow-Krzemińska, B., Czarnota, P., Łubek, A. \& Kukwa, M. (2016) Micarea soralifera sp. nov., a new sorediate species in the M. prasina group. Lichenologist 48: 161-169.

Hafellner, J. (1984) Studien in Richtung einer natürlicheren Gliederung der Sammelfamilien Lecanoraceae und Lecideaceae. Beiheft zur Nova Hedwigia 79: 241-371.

Hedlund, J. T. (1892) Kritische Bemerkungen über einige Arten der Flechtengattungen Lecanora (Ach.), Lecidea (Ach.) und Micarea (Fr.). Bihang till Kongliga Svenska Vetenskaps-Akademiens Handlingar III 18: $1-104$.

Kauff, F. \& Lutzoni, F. (2002) Phylogeny of the Gyalectales and Ostropales (Ascomycota, Fungi): among and within order relationships based on nuclear ribosomal RNA small and large subunits. Molecular Phylogenetics and Evolution 25: 138-156. 
Kirk, P. M., Cannon, P. F., Minter, D. W. \& Stalpers, J. A. (2008) Ainsworth \& Bisby’s Dictionary of the Fungi. 10th edition ed. CABI Publishing, UK.

Launis, A. \& Myllys, L. (2014) Micarea byssacea new to North America and M. hedlundii new to Maine, Michigan and Quebec. Opuscula Philolichenum 13: 84-90.

Leavitt, S. D., Johnson, L., Goward, T. \& St. Clair, L. (2011) Species delimitation in taxonomically difficult lichen-forming fungi: an example from morphologically and chemically diverse Xanthoparmelia (Parmeliaceae) in North America. Molecular Phylogenetics and Evolution 60: 317-32.

Lumbsch, H. T., Leavitt, S. D. 2011: Goodbye morphology? A paradigm shift in the delimitation of species in lichenized fungi. Fungal Diversity 50: 59-72.

Mark, K., Saag, L., Leavitt, S. D., Will-Wolf, S., Nelsen, M. P., Tõrra, T., Saag, A., Randlane, T. \& Lumbsch, H. T. (2016) Evaluation of traditionally circumscribed species in the lichen-forming genus Usnea, section Usnea (Parmeliaceae, Ascomycota) using a six-locus dataset. Organisms Diversity \& Evolution 16: 497524.

Maddison, D. R. \& Maddison, W. P. (2005) MacClade 4: Analysis of Phylogeny and Character Evolution. Sunderland, Massachusetts: Sinauer Associates.

McCarthy, P. M. \& Elix, J. A. (2016) A new species of Micarea (lichenized Ascomycota, Pilocarpaceae) from alpine Australia. Telopea 19: 31-35.

Meyer, B. \& Printzen, C. (2000) Proposal for a standardized nomenclature and characterization of insoluble lichen pigments. Lichenologist 32: 571-583.

Myllys, L., Lohtander, K., Källersjö, M. Tehler, A. (1999) Sequence insertion and ITS data provide congruent information in Roccella canariensis and R. tuberculata (Arthoniales, Euascomycetes) phylogeny. Molecular Phylogenetics and Evolution 12: 295-309.

Myllys, L., Velmala, S., Holien, H., Halonen, P., Wang, L. S. \& Goward, T. (2011) Phylogeny of the genus Bryoria. Lichenologist 43: 617-638. 
Orange, A., James, P. W. \& White, F. J. (2010) Microchemical methods for the identification of lichens. British Lichen Society 44-45.

Schmitt, I., Crespo, A., Divakar, P., Fankhauser, J., Herman-Sackett, E., Nelsen, M. (2009) New primers for single-copy protein-coding genes for fungal systematics. Persoonia 23: 35-40.

Schmull, M., Miadlikowska, J., Pelzer, M., Stocker-Wörgötter, E., Hofstetter, V., Fraker, E., Hodkinson, B., Reeb, V., Kukwa, M., Lumbsch, H. T. (2011) Phylogenetic affiliations of members of the heterogeneous lichen-forming fungi of the genus Lecidea sensu Zahlbruckner (Lecanoromycetes, Ascomycota). Mycologia 103: 983-1003.

Sérusiaux, E., Brand, A. M., Motiejūnaitè, J., Orange, A. \& Coppins, B. J. (2010) Lecidea doliiformis belongs to Micarea, Catillaria alba to Biatora and Biatora ligni-mollis occurs in western Europe. Bryologist 113: 333-344.

Spribille, T., Klung, B. \& Mayerhofer, H. (2011) A phylogenetic analysis of the boreal lichen Mycoblastus sanguinarius (Mycoblastaceae, lichenized Ascomycota) reveals cryptic clades correlated with fatty acid profiles. Molecular Phylogenetics and Evolution 59: 603-614.

Stamatakis, A. (2014) RAxML version 8: a tool for phylogenetic analysis and post-analysis of large phylogenies. Bioinformatics 30: 1312-1313.

Svensson, M. \& Thor, G. (2011) Micarea capitata, new bryophilous lichen from Sweden. Lichenologist 43: 401-405.

van den Boom, P. \& Coppins. B. J. (2001) Micarea viridileprosa sp. nov., an overlooked lichen species from Western Europe. Lichenologist 33: 87-91.

van den Boom, P. P. G. \& Ertz, D. (2014) A new species of Micarea (Pilocarpacea) from Madeira growing on Usnea. Lichenologist 46: 295-301.

van den Boom, P. P. G., Brand, A. M., Coppins, B. J. \& Sérusiaux, E. (2017) Two new species in the Micarea prasina group from Western Europe. Lichenologist 49: 13-25. 
White, T. J., Bruns, T., Lee, S., Taylor, J.W. (1990) Amplification and direct sequencing of fungal ribosomal RNA genes for phylogenetics. In: Innis, M. A., Gelfand, D. H., Sninsky, J. J., White, T. J., eds. PCR protocols: A guide to the methods and applications. New York, NY: Academic Press. p. 315-322.

Zoller, S., Scheidegger, C. \& Sperisen, C. (1999). PCR primers for the amplification of mitochondrial small subunit ribosomal DNA of lichen-forming Ascomycetes. Lichenologist 31: 511-516. 